\title{
Streptococcus peroris sp. nov. and Streptococcus infantis sp. nov., new members of the Streptococcus mitis group, isolated from human clinical specimens
}

\author{
Yoshiaki Kawamura, ${ }^{1}$ Xiao-Gang Hou, ${ }^{1}$ Yuko Todome, ${ }^{2}$ \\ Ferdousi Sultana, ${ }^{1}$ Kenji Hirose, ${ }^{1}$ Sin-Ei Shu, ${ }^{1}$ Takayuki Ezaki ${ }^{1}$ \\ and Hisashi Ohkuni
}

\begin{abstract}
Author for correspondence: Yoshiaki Kawamura. Tel: +81 58267 2240. Fax: +81 582670156. e-mail: kawamura@cc.gifu-u.ac.jp
\end{abstract}

\footnotetext{
1 Department of Microbiology, Gifu University School of Medicine, 40 Tsukasamachi, Gifu 500, Japan

2 Department of Immunology and Infectious Diseases, Institute of Gerontology, Nippon Medical School, 1-396, Kosugi-cho, Nakahara-ku, Kawasaki, Kanagawa 211, Japan
}

\begin{abstract}
Taxonomic studies were performed on eight strains of $\alpha$-haemolytic streptococci that showed very low DNA-DNA hybridization similarity values with all established members of the mitis group of the genus Streptococcus. These strains were isolated from the tooth surface and pharynx of humans. $16 S$ rRNA gene sequence analysis showed that these strains belonged to the mitis group, but that they fell into two new branches. DNA-DNA hybridization demonstrated two new similarity groups. From the results of the present study, the names Streptococcus peroris sp. nov. and Streptococcus infantis sp. nov. are proposed for these new groups. The type strains are $0-66^{\top}$ ( $=$ GTC $^{\mathrm{T}} 848^{\top}$ $\left.=\mathrm{JCM} 10158^{\top}\right)$ and $0-122^{\top}\left(=\right.$ GTC $\left.^{849^{\top}}=\mathrm{JCM} 10157^{\top}\right)$, respectively.
\end{abstract}

Keywords: $\alpha$-haemolytic streptococci, the mitis group, S. peroris, S. infantis, $16 \mathrm{~S}$ rRNA, DNA-DNA hybridization

\section{INTRODUCTION}

In the past decade, some species or species groups of the genus Streptococcus, such as the enterococci, lactococci, anaerobic streptococci and nutritionally variant streptococci, have been transferred to other genera (Collins \& Wallbanks, 1992; Ezaki et al., 1994; Kawamura et al., 1995a; Kilpper-Balz \& Schleifer, 1988; Schleifer \& Kilpper-Balz, 1984; Schleifer et al., 1985). At the same time, several new members of the genus Streptococcus have been proposed (Devriese et al., 1988, 1997; Eldar et al., 1994; Kilian et al., 1989; Osawa et al., 1995; Robinson et al., 1988; Skaar et al., 1994; Vandamme et al., 1996; Whiley et al., 1988, 1990; Whiley \& Hardie, 1988; Williams \& Collins, 1990). Presently, 42 species and four subspecies are recognized as members of the genus Streptococcus. $\alpha-$ Haemolytic streptococci, especially the members of the mitis group (Bentley et al., 1991; Kawamura et al., 1995b) have been considered difficult to classify and identify. In a previous DNA-DNA hybridization study, we confirmed the difficulty in identifying

The DDBJ accession numbers for the 16S rRNA sequences of $S$. peroris, S. infantis and S. cristatus are $A B 008314, A B 008315$ and $A B 008313$, respectively. members of the mitis group by biochemical methods; many strains identified biochemically as Streptococcus mitis, Streptococcus oralis or Streptococcus sanguinis (formerly Streptococcus sanguis) (Trüper \& de' Clari, 1997) remained unconfirmed by DNA-DNA hybridization (Ezaki et al., 1988). This difficulty in identification was due to a lack of reliable, accumulated biochemical traits. Furthermore, we believe that some previously undescribed taxa that should be classified as new species or subspecies were present among the clinical isolates that had been identified as members of the mitis group. Unfortunately, members of the mitis group are genetically closely related to each other, and it is very difficult to differentiate between them even by genetic methods; some members of the mitis group share more than $99 \% 16 \mathrm{~S}$ rRNA gene sequence similarity and show 40-60\% DNADNA homology (Kawamura et al., 1995b).

During the present taxonomic study of the mitis group, we have found that some clinical strains showing very low DNA-DNA homology to all members of the mitis group formed two separate groups. We have determined the phylogenetic position and biochemical traits of these strains, and we propose two new species, Streptococcus peroris and Streptococcus infantis. 
Table 1. DNA-DNA hybridization similarity values

Each value represents the mean of two experiments. We used 31 and $41{ }^{\circ} \mathrm{C}$ for optimal and stringent hybridization conditions, respectively. The hybridization solution contained $50 \%$ formamide, which decreased the hybridization temperature by approximately $30{ }^{\circ} \mathrm{C}(\mathrm{Meinkoth}$ \& Wahl, 1984)

\begin{tabular}{|c|c|c|c|c|c|c|c|c|c|}
\hline \multirow[t]{3}{*}{ Species/group } & \multirow[t]{3}{*}{ Strain } & \multicolumn{8}{|c|}{ Percentage DNA similarities with biotin-labelled DNA from: } \\
\hline & & \multicolumn{2}{|c|}{$0-66^{T}$} & \multicolumn{2}{|c|}{ O-105 } & \multicolumn{2}{|c|}{$\mathbf{0 - 1 2 2 ^ { T }}$} & \multicolumn{2}{|c|}{ O-134 } \\
\hline & & Optimal & Stringent & Optimal & Stringent & Optimal & Stringent & Optimal & Stringent \\
\hline \multicolumn{10}{|l|}{ Similarity group I } \\
\hline & $0-66^{\mathrm{T}}$ & $100 \cdot 0$ & $100 \cdot 0$ & $83 \cdot 4$ & $75 \cdot 1$ & $39 \cdot 5$ & $31 \cdot 4$ & $50 \cdot 5$ & $32 \cdot 0$ \\
\hline & O-91 & $96 \cdot 1$ & $94 \cdot 5$ & $98 \cdot 8$ & $99 \cdot 3$ & $35 \cdot 2$ & $24 \cdot 4$ & $61 \cdot 6$ & $23 \cdot 0$ \\
\hline & O-105 & $83 \cdot 7$ & $75 \cdot 3$ & $100 \cdot 0$ & $100 \cdot 0$ & $38 \cdot 8$ & $37 \cdot 8$ & $49 \cdot 5$ & $28 \cdot 2$ \\
\hline \multicolumn{10}{|c|}{ Similarity group II } \\
\hline & $\mathrm{O}-92$ & $39 \cdot 8$ & $30 \cdot 3$ & $53 \cdot 7$ & $30 \cdot 4$ & $77 \cdot 6$ & $75 \cdot 4$ & $76 \cdot 8$ & $81 \cdot 7$ \\
\hline & O-101 & $47 \cdot 9$ & $41 \cdot 0$ & $50 \cdot 6$ & $29 \cdot 6$ & $81 \cdot 1$ & $75 \cdot 3$ & $90 \cdot 4$ & $88 \cdot 7$ \\
\hline & O-103 & $57 \cdot 8$ & $52 \cdot 0$ & $61 \cdot 9$ & $40 \cdot 8$ & $73 \cdot 6$ & $76 \cdot 9$ & $73 \cdot 8$ & $71 \cdot 1$ \\
\hline & $\mathrm{O}-122^{\mathrm{T}}$ & $43 \cdot 7$ & $37 \cdot 7$ & $42 \cdot 3$ & $41 \cdot 2$ & $100 \cdot 0$ & $100 \cdot 0$ & $76 \cdot 3$ & $73 \cdot 3$ \\
\hline & O-134 & $55 \cdot 2$ & $35 \cdot 2$ & $53 \cdot 6$ & $34 \cdot 4$ & $80 \cdot 5$ & $75 \cdot 8$ & $100 \cdot 0$ & $100 \cdot 0$ \\
\hline S. mitis & GTC $495^{\mathrm{T}}\left(\mathrm{NCTC} 12261^{\mathrm{T}}\right)$ & $20 \cdot 4$ & $8 \cdot 6$ & $28 \cdot 6$ & $11 \cdot 7$ & $18 \cdot 8$ & $10 \cdot 6$ & $13 \cdot 8$ & $14 \cdot 5$ \\
\hline S. oralis & GTC $276^{\mathrm{T}}\left(\mathrm{NCTC} 11427^{\mathrm{T}}\right)$ & $19 \cdot 8$ & $11 \cdot 5$ & $32 \cdot 3$ & $14 \cdot 8$ & $23 \cdot 9$ & $11 \cdot 6$ & $17 \cdot 9$ & $18 \cdot 8$ \\
\hline S. pneumoniae & GTC $261^{\mathrm{T}}\left(\operatorname{NCTC} 7465^{\mathrm{T}}\right)$ & $21 \cdot 5$ & $13 \cdot 6$ & $27 \cdot 9$ & $22 \cdot 2$ & $26 \cdot 5$ & $15 \cdot 2$ & $21 \cdot 7$ & $17 \cdot 1$ \\
\hline S. gordonii & GTC $497^{\mathrm{T}}\left(\right.$ ATCC $\left.10558^{\mathrm{T}}\right)$ & $7 \cdot 3$ & $5 \cdot 2$ & $13 \cdot 1$ & $9 \cdot 2$ & $7 \cdot 5$ & $6 \cdot 4$ & $8 \cdot 3$ & $6 \cdot 0$ \\
\hline S. cristatus & GTC $631^{\mathrm{T}}\left(\right.$ ATCC $\left.12479^{\mathrm{T}}\right)$ & $16 \cdot 6$ & $13 \cdot 5$ & $17 \cdot 4$ & $12 \cdot 8$ & $13 \cdot 5$ & $7 \cdot 4$ & $17 \cdot 0$ & $7 \cdot 8$ \\
\hline S. sanguinis & GTC $217^{\mathrm{T}}\left(\right.$ ATCC $\left.10556^{\mathrm{T}}\right)$ & $8 \cdot 7$ & $4 \cdot 9$ & $13 \cdot 7$ & $7 \cdot 5$ & $8 \cdot 5$ & $4 \cdot 3$ & $7 \cdot 6$ & $5 \cdot 5$ \\
\hline S. parasanguinis & GTC $498^{\mathrm{T}}\left(\right.$ ATCC $\left.15912^{\mathrm{T}}\right)$ & $11 \cdot 0$ & $8 \cdot 4$ & $21 \cdot 9$ & $12 \cdot 8$ & $16 \cdot 2$ & $11 \cdot 2$ & $12 \cdot 4$ & $13 \cdot 0$ \\
\hline S. salivarius & GTC $215^{\mathrm{T}}\left(\right.$ ATCC $\left.7073^{\mathrm{T}}\right)$ & $15 \cdot 0$ & $11 \cdot 7$ & $16 \cdot 5$ & $10 \cdot 6$ & $10 \cdot 5$ & $6 \cdot 1$ & $14 \cdot 7$ & $7 \cdot 8$ \\
\hline S. bovis & GTC $235^{\mathrm{T}}\left(\right.$ NCFB $\left.597^{\mathrm{T}}\right)$ & $6 \cdot 6$ & $5 \cdot 4$ & $8 \cdot 0$ & $5 \cdot 8$ & 4.9 & $3 \cdot 6$ & $7 \cdot 7$ & $3 \cdot 3$ \\
\hline
\end{tabular}

\section{METHODS}

Strains and cultivation. Strains used in this study were virtually all isolated from human (3-month- to 3-year-old children from Tokyo) clinical sources between 1990 and 1991: O-66 ${ }^{\mathrm{T}}$ [GTC 848 ${ }^{\mathrm{T}}=\mathrm{JCM} 10158^{\mathrm{T}}$ ], pharynx, Kawasaki disease (KD); O-91, pharynx, KD; O-105, tooth surface, acute pharyngitis (group I); O-92, pharynx, KD; O-101, tooth surface, KD; O-103, pharynx, bronchiostenosis (group II). Strains O-122 $\left[\right.$ GTC $\left.849^{\mathrm{T}}=\mathrm{JCM} 10157^{\mathrm{T}}\right]$ and O-134 (group II) were isolated from the pharynx of a healthy Japanese child in 1990 (location unknown) and from the human pharynx (KD status, date and location unknown), respectively (Ohkuni et al., 1993). These strains were grown on Columbia blood (5\% defibrinated sheep blood) agar plates (CBA; bioMérieux) at $37^{\circ} \mathrm{C}$ under aerobic conditions.

Microplate DNA-DNA hybridization. Quantitative microplate DNA-DNA hybridization was carried out as described previously (Ezaki et al., 1989). Hybridization experiments were carried out at $31{ }^{\circ} \mathrm{C}$ (optimal conditions) and $41{ }^{\circ} \mathrm{C}$ (stringent conditions) using $2 \times \mathrm{SSC}$ and $50 \%$ formamide. The optimal temperature was $55^{\circ} \mathrm{C}$ lower than the thermal denaturation temperature; because formamide lowered the hybridization temperature (Meinkoth \& Wahl, 1984).

The type strains used for DNA-DNA hybridization were as follows: Streptococcus mitis GTC $495^{\mathrm{T}}\left(=\right.$ NCTC 12261 $\left.{ }^{\mathrm{T}}\right)$, Streptococcus oralis GTC $276^{\mathrm{T}}\left(=\right.$ NCTC $\left.11427^{\mathrm{T}}\right)$, Streptococcus pneumoniae GTC $261^{\mathrm{T}}$ (= NCTC $\left.7465^{\mathrm{T}}\right)$, Streptococcus gordonii $\mathrm{GTC} 497^{\mathrm{T}}\left(=\mathrm{ATCC} 10558^{\mathrm{T}}\right)$, Streptococcus cristatus [formerly Streptococcus crista (Trüper \& de' Clari, 1997)] GTC 631 ${ }^{\mathrm{T}}$ (= NCTC $12479^{\mathrm{T}}$ ), Streptococcus sanguinis
GTC $217^{\mathrm{T}}$ (= ATCC $10556^{\mathrm{T}}$ ), Streptococcus parasanguinis [formerly Streptococcus parasanguis (Trüper \& de' Clari, 1997)] GTC 498 ${ }^{\mathrm{T}}$ (= ATCC 15912 ${ }^{\mathrm{T}}$ ), Streptococcus bovis GTC $235^{\mathrm{T}}\left(=\right.$ NCFB $\left.597^{\mathrm{T}}\right)$, and Streptococcus salivarius GTC $215^{\mathrm{T}}\left(=\mathrm{ATCC} 7073^{\mathrm{T}}\right)$.

Mol\% G + C content of DNA. The mol $\% \mathrm{G}+\mathrm{C}$ content of the DNA was determined by HPLC as described previously (Ezaki et al., 1990). Briefly, $10 \mu \mathrm{l}$ purified DNA (1 $\left.\mathrm{mg} \mathrm{m}^{-1}\right)$ was heat-denatured, and after cooling the DNA solution, $10 \mu \mathrm{l}$ Nuclease $\mathrm{P} 1$ solution $\left(2 \mathrm{U} \mathrm{ml}^{-1}\right)$ was added and incubated at $50^{\circ} \mathrm{C}$ for $1 \mathrm{~h}$. Then $10 \mu \mathrm{l}$ alkaline phosphatase solution $\left(2.4 \mathrm{U} \mathrm{ml}^{-1}\right)$ was added and allowed to incubate at $37^{\circ} \mathrm{C}$ for $30 \mathrm{~min}$. The digested DNA solution was analysed by HPLC using a packed column (Wakosil 5C18; Wako). The $\mathrm{G}+\mathrm{C}$ content was calculated based on the Escherichia coli $\mathrm{K}-12$ strain DNA as a standard $(51 \cdot 12 \mathrm{~mol} \% \mathrm{G}+\mathrm{C})$.

165 rRNA gene sequence and analysis. The 16S rRNA genes were amplified by PCR as previously described (Ezaki et al., 1994). The sequence was determined using an automatic sequencer (ALF-express) with an auto-load sequencing kit (both from Pharmacia Biotech). The sequence from positions 45-1380 (E. coli numbering) of each 16S rRNA was determined.

The sequences of the other members of the genus Streptococcus used for alignment and for calculating the homology levels were obtained from the DDBJ, GenBank and EMBL databases. The CLUSTAL $\mathrm{W}$ software originally described by Thompson et al. (1994) was used to align the sequences, and the phylogenetic distance was calculated using the neighbour-joining method. The phylogenetic tree was drawn using TREEVIEW software. 
Biochemical traits. The biochemical traits were determined with Rapid ID32 Strep (bioMérieux) and STREPTOGRAM (Wako) (Kawamura et al., 1995c) according to the manufacturers' recommendations. We confirmed the hydrolytic ability of arginine in Moeller-decarboxylase medium containing $1 \% \mathrm{D}$-arginine. We also determined aesculin hydrolysis in a heart infusion broth containing $0.1 \%$ aesculin and $0.05 \%$ ferric citrate. After inoculation into these media, cultures were observed continuously for 1 week.

\section{RESULTS}

\section{Colony morphology}

All strains of group I formed pin-point colonies (less than $0.1 \mathrm{~mm}$ in diameter) on CBA-plates at $37^{\circ} \mathrm{C}$ under aerobic conditions after $1 \mathrm{~d}$ incubation. After $3 \mathrm{~d}$ incubation, they made 'middle size' colonies (approximately $0.3-0.8 \mathrm{~mm}$ in diameter). The strains of group II also formed small colonies after $1 \mathrm{~d}$ incubation. However, they grew more rapidly than the strains of group I, and they made colonies $0.3-0.8 \mathrm{~mm}$ in diameter after $2 \mathrm{~d}$ incubation. All strains of groups I and II showed $\alpha$-haemolysis on CBA plates.

\section{DNA-DNA hybridization}

The DNA-DNA hybridization similarity values obtained under optimal $\left(31^{\circ} \mathrm{C}\right)$ and stringent $\left(41^{\circ} \mathrm{C}\right)$ conditions are shown in Table 1 . Three strains of group I showed more than 83 and $75 \%$ similarity under optimal and stringent conditions, respectively. Similarly, five strains of group II showed more than $71 \%$ similarity under both optimal and stringent conditions. These two new groups showed less than $33 \%$ similarity to all established members of the mitis group as well as to other $\alpha$-haemolytic streptococci $(S$. salivarius and $S$. bovis). These data clearly demonstrated that these two new groups were genetically independent taxa.

\section{S rRNA analysis}

Before we performed the phylogenetic analysis of groups I and II, we determined the 16S rRNA sequence and phylogenetic position of the type strain of $S$. cristatus, as this species had previously been designated as $S$. sanguinis and was strongly suspected of belonging to the mitis group. As expected, the branching root of $S$. cristatus was located within the mitis group cluster, and the highest level of sequence homology to $S$. cristatus was exhibited by $S$. sanguinis $(97 \cdot 1 \%)$.

The sequences from positions 45 to 1380 (E. coli numbering) of the $16 \mathrm{~S}$ rRNAs of strains $\mathrm{O}-66^{\mathrm{T}}$ and O$122^{\mathrm{T}}$ were determined. We also determined the partial sequences of the 16S rRNA gene (about $500 \mathrm{bp}$ from the $5^{\prime}$ end, which includes V1, V2 and V3 areas) from six other strains. The three strains of group I shared complete sequence homology within this $500 \mathrm{bp}$ region. The five strains of group II shared almost identical sequences with each other. Each of these

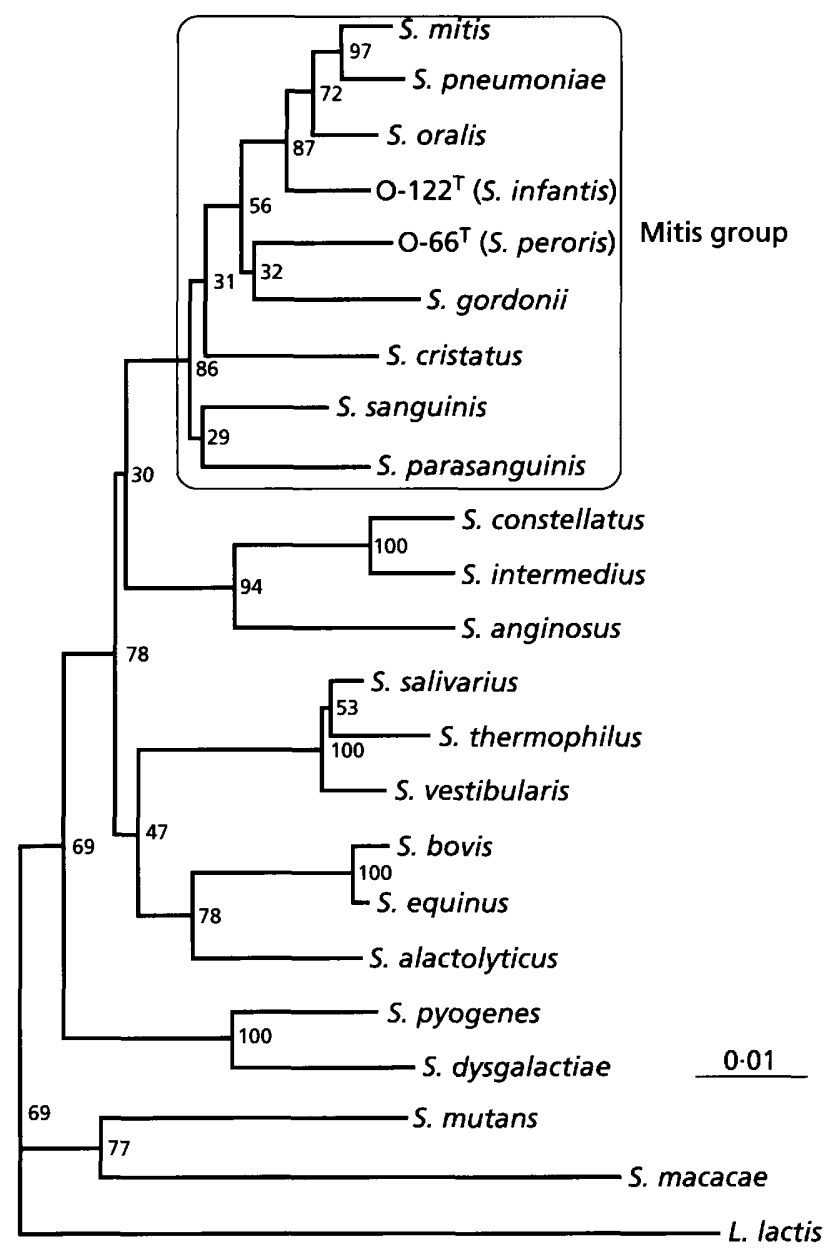

Fig. 1. Phylogenetic positions of two new similarity groups and $S$. cristatus among selected members of the genus Streptococcus. Distances were calculated by the neighbourjoining method. The numbers at the branching points are bootstrap values. Lactococcus lactis was used as the outgroup. $16 \mathrm{~S}$ rRNA sequence accession numbers; 'S. peroris', AB008314; 'S. infantis', AB008315; S. mitis, D38482; S. oralis, X58308; S. pneumoniae, X58312; S. gordonii, D38483; S. cristatus, $\mathrm{AB008313;}$ S. sanguinis, $\times 53653$; S. parasanguinis, $\times 53652$; S. anginosus, $X 58309 ; S$. constellatus, $X 58310 ; S$. intermedius, $\mathrm{X} 58311$; S. salivarius, X58320; S. thermophilus, X68418; S. vestibularis, X58321; S. bovis, M58835; S. alactolyticus, X58319; S. equinus, X58318; S. mutans, X58303; S. macacae, X58302; S. dysgalactiae, X59030; L. lactis, M58837.

latter strains possessed only 1-4 different bases from the $\mathrm{O}-122^{\mathrm{T}}$ sequence.

We investigated the phylogenetic position of representative strains of each group (strains $0-66^{\mathbf{T}}$ and $\mathrm{O}$ $122^{\mathrm{T}}$ ). The phylogenetic analysis demonstrated that the branching roots of the two new groups were located within the mitis group, as shown in Fig. 1. Group I was clustered with $S$. gordonii. Group II was clustered with the $S$. mitis $-S$. oralis-S. pneumoniae branch.

The highest levels of sequence homology, and therefore 
Table 2. Levels of $16 \mathrm{~S}$ rRNA sequence homology among the strains of two new similarity groups and other members of the genus Streptococcus

\begin{tabular}{|c|c|c|c|}
\hline \multirow[t]{2}{*}{ Group } & \multirow[t]{2}{*}{ Strain/species } & \multicolumn{2}{|c|}{$\begin{array}{c}\text { Percentage homology } \\
\text { with: }\end{array}$} \\
\hline & & $0-66$ & $0-122^{T}$ \\
\hline \multirow{8}{*}{ Mitis } & $\mathrm{O}-66^{\mathrm{T}}$ & $100 \cdot 0$ & \\
\hline & $\mathrm{O}-122^{\mathrm{T}}$ & $97 \cdot 2$ & $100 \cdot 0$ \\
\hline & S. mitis & $97 \cdot 2$ & $98 \cdot 4$ \\
\hline & S. oralis & $96 \cdot 9$ & $98 \cdot 3$ \\
\hline & S. pneumoniae & $97 \cdot 1$ & $98 \cdot 3$ \\
\hline & S. gordonii & 96.9 & $97 \cdot 2$ \\
\hline & S. cristatus & $96 \cdot 4$ & $96 \cdot 8$ \\
\hline & S. sanguinis & $96 \cdot 4$ & $97 \cdot 5$ \\
\hline \multirow{4}{*}{ Anginosus } & S. parasanguinis & $96 \cdot 1$ & $96 \cdot 8$ \\
\hline & $S$. anginosus & $94 \cdot 4$ & $93 \cdot 8$ \\
\hline & S. constellatus & $94 \cdot 6$ & $95 \cdot 0$ \\
\hline & S. intermedius & $95 \cdot 0$ & $94 \cdot 6$ \\
\hline \multirow[t]{3}{*}{ Salivarius } & S. salivarius & $96 \cdot 3$ & $95 \cdot 4$ \\
\hline & S. thermophilus & $95 \cdot 6$ & $94 \cdot 8$ \\
\hline & S. vestibularis & $95 \cdot 9$ & $95 \cdot 1$ \\
\hline \multirow[t]{3}{*}{ Bovis } & S. bovis & $95 \cdot 9$ & $95 \cdot 0$ \\
\hline & S. alactolyticus & $95 \cdot 2$ & $95 \cdot 7$ \\
\hline & S. equinus & $95 \cdot 9$ & $95 \cdot 0$ \\
\hline \multirow[t]{2}{*}{ Mutans } & S. mutans & $93 \cdot 2$ & $92 \cdot 9$ \\
\hline & S. macacae & $91 \cdot 1$ & $90 \cdot 3$ \\
\hline \multirow[t]{2}{*}{ Pyogenic } & S. pyogenes & $94 \cdot 2$ & $94 \cdot 1$ \\
\hline & S. dysgalactiae & $93 \cdot 2$ & $94 \cdot 5$ \\
\hline
\end{tabular}

the closest relationships, were found to be between group I, group II and S. mitis (Table 2).

\section{Biochemical characteristics}

Biochemical traits were determined using two different commercially available kits (Rapid ID32 Strep and STREPTOGRAM). The biochemical reaction patterns are shown in Table 3. All strains of group I gave a positive reaction for acidification of lactose, maltose and sucrose, and production of $\beta$-D-galactosidase (only from the substrate $p$-nitrophenyl $\beta$-Dgalactopyranoside) and alanine-phenylalanine-proline-arylamidase (APPA). All strains gave a negative reaction for arginine and aesculin hydrolysis with both commercial kits and the conventional tests. Only one strain gave a positive reaction for alkaline phosphatase. All strains of group II gave a positive reaction for acidification of lactose, maltose, sucrose and tagatose, and production of $\beta$-D-galactosidase (from both $p$ nitrophenyl $\beta$-D-galactopyranoside and 2-naphthyl $\beta$ D-galactopyranoside substrates), APPA and glycinetryptophan arylamidase. All strains of group II gave a negative reaction for arginine and aesculin hydrolysis with both commercial kits and the conventional tests. Only one strain gave a positive reaction for acidification of inulin and pullulan. Three strains gave a positive reaction for the production of $\beta$-D-fucosidase and $N$-acetyl- $\beta$-D-glucosaminidase. Only one strain gave a weak reaction for pyrrolidonyl arylamidase.

Rapid ID32 Strep kit profile numbers for O-66 ${ }^{\mathrm{T}}$ and $\mathrm{O}-122^{\mathrm{T}}$ were 44012001100 and 40016641120 , respectively.

\section{G + C content of DNA}

The DNA G + C contents of strains O- $66^{\mathrm{T}}$ and $\mathrm{O}-122^{\mathrm{T}}$ were $39 \cdot 8 \pm 0 \cdot 1$ and $40 \cdot 1 \pm 0 \cdot 1 \mathrm{~mol} \%$, respectively. The DNA $\mathrm{G}+\mathrm{C}$ contents of groups I and II were $39.8-40.5 \mathrm{~mol} \% \quad($ mean $=40.0 \mathrm{~mol} \%)$ and 39.9 $40.4 \mathrm{~mol} \%($ mean $=40.1 \mathrm{~mol} \%)$, respectively.

\section{DISCUSSION}

From the DNA-DNA hybridization results, the strains of groups I and II formed completely separate groups, showing more than $75 \%$ DNA similarity with their respective representative strains $\left(\mathrm{O}-66^{\mathrm{T}}\right.$ and $\mathrm{O}$ $122^{\mathrm{T}}$ ) even under stringent conditions. In contrast, less than $30 \%$ DNA similarity was obtained with the seven type strains of currently recognized members of the mitis group. The genomic similarity values showed that groups I and II were closely related to each other, since they shared 40-60\% DNA similarity (Table 1). However they shared only $97.2 \% \quad 16 \mathrm{~S}$ rRNA gene sequence homology. This value was lower than that obtained for group II with $S$. mitis, $S$. oralis, $S$. pneumoniae or $S$. sanguinis (Table 2). Furthermore, the phylogenetic tree showed that the branching roots of groups I and II were slightly separated and were clustered with the $S$. gordonii and $S$. mitis $-S$. oralis $-S$. pneumoniae branches, respectively (Fig. 1). Therefore, the genetic relationships deduced from the DNADNA hybridization data and from the16S rRNA sequence data were different.

There are three registrated 16S rRNA gene sequences of the type strain of $S$. sanguinis in the database (accession numbers X53653, AF003928 and AB002524). They have 4-13 base differences within the same area (about $1300 \mathrm{bp}$ ). We could not explain the actual reason for this sequence variation, however the possible reason is technical, leading to mis-determination of sequence or sequence determination from different copies of the $16 \mathrm{~S}$ rRNA gene. Nevertheless, with use of any one of these registrated sequence data, $S$. sanguinis is still located in the mitis group, even if the branching root is slightly different than that in Fig. 1 (data not shown).

The group I strains showed a positive $\beta$-galactosidase reaction only from the substrate $p$-nitrophenyl $\beta$-Dgalactopyranoside (Table 3). At least three substrates have been used for the detection of $\beta$-galactosidase activity (2-naphthyl $\beta$-D-galactopyranoside, $p$-nitrophenyl $\beta$-D-galactopyranoside and 4-methylumbelliferyl $\beta$-D-galactopyranoside) (Beighton et al., 1991; bioMérieux). Most likely, the collective data for $\beta$ galactosidase has been using the substrate 2-naphthyl 
Table 3. Biochemical characteristics of the new similarity groups I and II

R, Determined with Rapid ID32 Strep kit; S, determined with Streptogram kit; C, determined by conventional methods. - , negative; + , positive; $d$, variable. The numbers in parentheses are the number of positive strain(s)/test strains.

\begin{tabular}{|c|c|c|c|c|}
\hline \multirow[t]{2}{*}{ Character (method used) } & \multicolumn{2}{|c|}{ Group I (S. peroris) } & \multicolumn{2}{|c|}{ Group II (S. infantis) } \\
\hline & $\begin{array}{l}\text { All isolates } \\
\text { (3 strains) }\end{array}$ & $0-66^{T}$ & $\begin{array}{l}\text { All isolates } \\
\text { (5 strains) }\end{array}$ & $0-122^{\mathrm{T}}$ \\
\hline Haemolysis on sheep blood agar plate & $\alpha$ & $\alpha$ & $\alpha$ & $\alpha$ \\
\hline \multicolumn{5}{|l|}{ Acidification of: } \\
\hline Amygdalin (S) & - & - & - & - \\
\hline L-Arabinose $(\mathrm{R}, \mathrm{S})$ & - & - & - & - \\
\hline D-Arabitol (R) & - & - & - & - \\
\hline Arbutin (S) & - & - & - & - \\
\hline Cyclodextrine (R) & - & - & - & - \\
\hline Glycogen $(\mathrm{R})$ & - & - & - & - \\
\hline Inulin (S) & - & - & $d(1 / 5)$ & - \\
\hline Lactose $(\mathrm{R}, \mathrm{S})$ & + & + & + & + \\
\hline Maltose $(\mathrm{R})$ & + & + & + & + \\
\hline Mannitol (R, S) & - & - & - & - \\
\hline Methyl $\beta$-D-glucopyranoside (R) & - & - & - & - \\
\hline Melibiose (R, S) & - & - & - & - \\
\hline Melezitose (R) & - & - & - & - \\
\hline Pullulane (R) & - & - & $d(1 / 5)$ & + \\
\hline Raffinose $(\mathrm{R}, \mathrm{S})$ & - & - & - & - \\
\hline Ribose (R) & - & - & - & - \\
\hline Sucrose $(\mathrm{R})$ & + & + & + & + \\
\hline Sorbitol $(\mathrm{R}, \mathrm{S})$ & - & - & - & - \\
\hline Tagatose $(\mathbf{R})$ & - & - & + & + \\
\hline Trehalose $(\mathrm{R}, \mathrm{S})$ & - & - & - & - \\
\hline \multicolumn{5}{|l|}{ Production of: } \\
\hline$\alpha$-Galactosidase (R, S) & - & - & - & - \\
\hline$\beta$-Galactosidase $(\mathrm{R})^{*}$ & - & - & + & + \\
\hline$\beta$-Galactosidase $(\mathrm{R}, \mathrm{S}) \dagger$ & + & + & + & + \\
\hline $\begin{array}{l}\text { Alanyl-phenylalanyl-proline } \\
\text { arylamidase }(R)\end{array}$ & + & + & + & + \\
\hline$\beta$-Glucosidase (R) & - & - & - & - \\
\hline$\beta$-Mannosidase (R) & - & - & - & - \\
\hline$\beta$-D-Fucosidase (S) & - & - & $d(3 / 5)$ & + \\
\hline$\beta$-Glucuronidase $(\mathrm{R}, \mathrm{S})$ & - & - & - & - \\
\hline Glycine-tryptophan arylamidae (R) & - & - & + & + \\
\hline$N$-Acetyl- $\beta$-glucosaminidase $(\mathrm{R}, \mathrm{S})$ & - & - & $d(3 / 5)$ & + \\
\hline Alkaline phosphatase $(\mathbf{R}, \mathbf{S})$ & $d(1 / 3)$ & + & - & - \\
\hline Pyrollidonyl arylamidase $(\mathrm{R}, \mathrm{S})$ & - & - & $d(1 / 5)$ & - \\
\hline Urease $(\mathbf{R})$ & - & - & - & - \\
\hline VP-reaction (R, S) & - & - & - & - \\
\hline \multicolumn{5}{|l|}{ Hydrolysis of: } \\
\hline Arginine $(\mathrm{R}, \mathrm{S}, \mathrm{C})$ & - & - & - & - \\
\hline Aesculin $(S, C)$ & - & - & - & - \\
\hline Hippurate $(\mathrm{R}, \mathrm{S})$ & - & - & - & - \\
\hline
\end{tabular}

* Substrate is 2-naphthyl $\beta$-D-galactopyranoside.

$\dagger$ Substrate is $p$-nitrophenyl $\beta$-D-galactopyranoside.

$\beta$-D-galactopyranoside; as used in the API-ZYM and API 20 Strep identification test kits (bioMérieux). Using these commercial kits, the strains of group I were judged to have no $\beta$-galactosidase activity, however they could degrade the substrate $p$-nitrophenyl $\beta$-D-galactopyranoside. 
Table 4. Biochemical characteristics that differentiate the new species from other members of the mitis group

Data taken from Kikuchi et al. (1995), except that in parentheses which was our observation. + , More than $90 \%$ of strains positive; - , less than $10 \%$ of strains positive; $d+, 50-89 \%$ of strains positive; $d-, 11-49 \%$ of strains positive.

Substrates/products: 1 , arginine; 2 , melibiose; 3 , raffinose; 4 , trehalose; 5 , tagatose; 6 , $\alpha$-galactosidase; $7, \beta$-galactosidase ; $8, N$-acetyl- $\beta$-glucosaminidase; $9, \beta$-glucosidase; 10 , alkaline phosphatase.

\begin{tabular}{|c|c|c|c|c|c|c|c|c|c|c|}
\hline \multirow[t]{2}{*}{ Species } & \multirow{2}{*}{$\frac{\text { Hydrolysis of: }}{5}$} & \multicolumn{4}{|c|}{ Acidification of: } & \multicolumn{5}{|c|}{ Production of: } \\
\hline & & 2 & 3 & 4 & & 6 & $7^{*}$ & 8 & 9 & 10 \\
\hline S. peroris & - & - & - & - & - & - & - & - & - & $d-$ \\
\hline S. infantis & - & - & - & - & + & - & + & $\mathrm{d}+$ & - & - \\
\hline S. mitis & - & $\mathrm{d}-$ & $d-$ & - & - & $d-$ & - & - & - & $d+$ \\
\hline S. oralis & - & $d+$ & $d+$ & $d-$ & $d-(-)$ & $d+$ & $\mathrm{d}-$ & $\mathrm{d}-$ & - & $d+$ \\
\hline S. pneumoniae $\dagger$ & $\mathrm{d}-$ & - & + & + & - & + & - & $\mathrm{d}+$ & $\mathrm{d}-$ & - \\
\hline S. gordonii & + & - & - & + & $d-$ & - & - & - & $d+$ & + \\
\hline S. cristatus & + & $d-$ & $d-$ & $d+$ & $\mathrm{d}+$ & $d-$ & $d-$ & - & - & - \\
\hline S. sanguinis & + & $d+$ & $d+$ & + & $\mathrm{d}-$ & $d+$ & - & - & $d+$ & - \\
\hline S. parasanguinis & + & $d+$ & $d+$ & $\mathrm{d}-$ & $d+$ & $d+$ & $d-$ & $\mathrm{d}-$ & $\mathrm{d}-$ & $d+$ \\
\hline
\end{tabular}

* The substrate is 2-naphthyl $\beta$-D-galactopyranoside.

$\uparrow$ Only for $S$. pneumoniae, data taken from Rapid ID32 Strep database (bioMérieux).

Strains of group II showed similar biochemical traits to $S$. mitis or $S$. oralis. However, some biochemical reactions, such as alkaline phosphatase, $\beta$-galactosidase (substrate is 2-naphthyl $\beta$-D-galactopyranoside) and tagatose acidification, are helpful for differentiating group II strains from these species (Table 4). The tagatose acidification test is only used in the Rapid ID32 Strep kit and was not performed using a conventional method. All $S$. mitis strains were negative for tagatose acidification in the Rapid ID32 Strep test kit as previously reported by Kikuchi et al. (18). The proportion of strains of $S$. oralis positive for this test is $30 \%$ and $40 \%$, according to the Rapid ID32 Strep database and Kikuchi et al. (1995), respectively. However, in studies undertaken in our laboratory, only $10 \%(3 / 30)$ of $S$. oralis strains which were clearly classified by quantitative plate DNA-DNA hybridization, showed a positive reaction for tagatose acidification (unpublished data), compared with all strains of group II which gave positive reactions in this test.

In view of the data presented above, we believe that these two groups should be classified as new species. We propose the names Streptococcus peroris sp. nov. and Streptococcus infantis sp. nov. for groups I and II, respectively.

\section{Description of Streptococcus peroris sp. nov.}

Streptococcus peroris (per.or.is. L. adj. per through; L. n. oris oral cavity; L. adj. peroris pertaining to the oral cavity, from where the organism was isolated).

Cells are non-sporulating, non-motile, Gram-positive, catalase-negative cocci that are approximately $0.6-0.8 \mathrm{~mm}$ in diameter, and grow in short chains.
Facultatively anaerobic. $\alpha$-Haemolytic on Columbia blood (sheep) agar plates. The biochemical characteristics of the species are shown in Table 3. The G+C content of the DNA is $39.8-40.5 \mathrm{~mol} \%$ (HPLC method). Strains are isolated from the human tooth surface and pharynx. The type strain is strain $\mathrm{O}-66^{\mathrm{T}}$ $\left(=\mathrm{GTC} 848^{\mathrm{T}}=\mathrm{JCM} 10158^{\mathrm{T}}\right)$.

\section{Description of Streptococcus infantis sp. nov.}

Streptococcus infantis (in.fant.is. L. n. infans infant; L. adj. infantis pertaining to human infants, from whom the organism was isolated).

Cells are non-sporulating, non-motile, Gram-positive, catalase-negative cocci that are approximately $0.6-1.0 \mathrm{~mm}$ in diameter, and grow singly or in short chains. Facultatively anaerobic. $\alpha$-Haemolytic on Columbia blood (sheep) agar plates. The biochemical characteristics of the species are shown in Table 3. The $\mathrm{G}+\mathrm{C}$ content of the DNA is $39 \cdot 9-40.4 \mathrm{~mol} \%$ (HPLC method). Strains are isolated from the human tooth surface and pharynx. The type strain is strain $\mathrm{O}-122^{\mathrm{T}}$ $\left(=\right.$ GTC $849^{\mathrm{T}}=$ JCM $\left.10157^{\mathrm{T}}\right)$.

\section{ACKNOWLEDGEMENTS}

This work was partially supported by a Grant-in-Aid for Scientific Research (B)-09557024 from the Ministry of Education, Science and Culture of Japan.

\section{REFERENCES}

Beighton, D., Hardie, J. M. \& Whiley, R. A. (1991). A scheme for identification of viridans streptococci. $J$ Med Microbiol 35, 367-372. 
Bentley, R. W., Leigh, J. A. \& Collins, M. D. (1991). Intragenic structure of Streptococcus based on comparative analysis of small-subunit rRNA sequences. Int J Syst Bacteriol 41, 487-494.

Collins, M. D. \& Wallbanks, S. (1992). Comparative sequence analyses of the 16S rRNA genes of Lactobacillus minutus, Lactobacillus rimae and Streptococcus parvulus: proposal for the creation of a new genus Atopobium. FEMS Microbiol Lett 95, 235-240.

Devriese, L. A., Kilpper-Balz, R. \& Schleifer, K. H. (1988). Streptococcus hyointestinalis sp. nov. from the gut of swine. Int J Syst Bacteriol 38, 440-441.

Devriese, L. A., Pot, B., Vandamme, P., Kersters, K., Collins, M. D., Alvarez, N., Haesebrouck, F. \& Hommez, J. (1997). Streptococcus hyovaginalis sp. nov. and Streptococcus thoraltensis sp. nov., from the genital tract of sows. Int J Syst Bacteriol 47, 1073-1077.

Eldar, A., Bejerano, Y. \& Bercovier, H. (1994). Streptococcus shiloi and Streptococcus difficile: two new streptococcal species causing a meningoencephalitis in fish. Curr Microbiol 28, 139-143.

Ezaki, T., Hashimoto, Y., Takeuchi, N., Yamamoto, H., Liu, S., Miura, H., Matsui, K. \& Yabuuchi, E. (1988). Simple genetic method to identify viridans group streptococci by colorimetric dot hybridization and fluorometric hybridization in microdilution wells. J Clin Microbiol 26, 1708-1713.

Ezaki, T., Hashimoto, Y. \& Yabuuchi, E. (1989). Fluorometric deoxyribonucleic acid-deoxyribonucleic acid hybridization in microdilution wells as an alternative to membrane filter hybridization in which radioisotopes are used to determine genetic relatedness among bacterial strains. Int $J$ Syst Bacteriol 39, 224-229.

Ezaki, T., Saidi, S. M., Liu, S.-L., Hashimoto, Y., Yamamoto, H. \& Yabuuchi, E. (1990). Rapid procedure to determine the DNA base composition from small amounts of gram-positive bacteria. FEMS Microbiol Lett 67, 127-130.

Ezaki, T., Li, N., Hashimoto, Y., Miura, H. \& Yamamoto, H. (1994). 16S ribosomal DNA sequences of anaerobic cocci and proposal of Ruminococcus hansenii comb. nov. and Ruminococcus productus comb. nov. Int J Syst Bacteriol 44, 130-136.

Handley, P., Coykendall, A., Beighton, D., Hardie, J. M. \& Whiley, R. A. (1991). Streptococcus crista sp. nov. a viridans streptococcus with tufted fibrils, isolated from the human oral cavity and throat. Int J Syst Bacteriol 41, 543-547.

Kawamura, Y., Hou, X. G., Sultana, F., Liu, S., Yamamoto, H. \& Ezaki, T. (1995a). Transfer of Streptococcus adjacens and Streptococcus defectivus to Abiotrophia gen. nov. as Abiotrophia adiacens comb. nov. and Abiotrophia defectiva comb. nov., respectively. Int J Syst Bacteriol 45, 798-803.

Kawamura, Y., Hou, X. G., Sultana, F., Miura, H. \& Ezaki, T. (1995b). Determination of 16S rRNA sequences of Streptococcus mitis and Streptococcus gordonii and phylogenetic relationships among members of the genus Streptococcus. Int $J$ Syst Bacteriol 45, 406-408.

Kawamura, Y., Sultana, F., Hou, X. G. \& Ezaki, T. (1995c). Evaluation of a new streptococcal identification kit 'STREPTOGRAM'. J Jpn Soc Clin Microbiol 5, 4-12 (in Japanese).

Kilian, M., Mikkelsen, L. \& Henrichsen, J. (1989). Taxonomic study of viridans streptococci: description of Streptococcus gordonii sp. nov. and emended descriptions of Streptococcus sanguis (White and Niven 1946), Streptococcus oralis (Bridge and Sneath 1982), and Streptococcus mitis (Andrewes and Horder 1906). Int J Syst Bacteriol 39, 471-484.

Kilpper-Balz, R. \& Schleifer, K. H. (1988). Transfer of Streptococcus morbillorum to the genus Gemella as Gemella morbillorum comb. nov. Int J Syst Bacteriol 38, 442-443.

Kikuchi, K., Enari, T., Totsuka, K. \& Shimizu, K. (1995). Comparison of phenotypic characteristics, DNA-DNA hybridization results, and results with a commercial rapid biochemical and enzymatic reaction system for identification of viridans group streptococci. J Clin Microbiol 33, 1215-1222.

Meinkoth, J. \& Wahl, G. (1984). Hybridization of nucleic acids immobilized on solid supports. Anal Chem 138, 267-284.

Ohkuni, M., Todome, Y., Mizuse, M. \& 9 other authors (1993). Biologically active extracellular products of oral viridans streptococci and the aetiology of Kawasaki disease. $J$ Med Microbiol 39, 352-362.

Osawa, R., Fujisawa, T. \& Sly, L. I. (1995). Streptococcus gallolyticus sp. nov.; gallate degrading organisms formerly assigned to Streptococcus bovis. Syst Appl Microbiol 18, 74-78.

Robinson, I. M., Stromley, J. M., Varel, V. H. \& Cato, E. P. (1988). Streptococcus intestinalis, a new species from the colons and feces of pigs. Int J Syst Bacteriol 38, 245-248.

Schleifer, K. H. \& Kilpper-Balz, R. (1984). Transfer of Streptococcus faecalis and Streptococcus faecium to the genus Enterococcus nom. rev. as Enterococcus faecalis comb. nov. and Enterococcus faecium comb. nov. Int J Syst Bacteriol 34, 31-34.

Schleifer, K. H., Kraus, J., Dvorak, C., Kilpper-Balz, R., Collins, M. D. \& Fischer, W. (1985). Transfer of Streptococcus lactis and related streptococci to the genus Lactococcus gen. nov. Syst Appl Microbiol 6, 183-195.

Skaar, I., Gaustad, P., Tonjum, T., Holm, B. \& Stenwig, H. (1994). Streptococcus phocae sp. nov., a new species isolated from clinical specimens from seals. Int J Syst Bacteriol 44, 646-650.

Thompson, J. D., Higgins, D. G. \& Gibson, T. J. (1994). CLUSTAL $\mathrm{W}$ : improving the sensitivity of progressive multiple sequence alignment through sequence weighing, position-specific gap penalties and weight matrix choice. Nucleic Acids Res 22, 4673-4680.

Trüper, H. G. \& de' Clari, L. (1997). Taxonomic note: necessary correction of specific epithets formed as substantives (nouns) in 'apposition'. Int J Syst Bacteriol 47, 908.

Vandamme, P., Pot, B., Falsen, E., Kersters, K. \& Devriese, L. A. (1996). Taxonomic study of Lancefield streptococcal groups $C$, $\mathrm{G}$, and L (Streptococcus dysgalactiae) and proposal of $S$. dysgalactiae subsp. equisimilis subsp. nov. Int J Syst Bacteriol 46, 774-781.

Whiley, R. A. \& Hardie, J. M. (1988). Streptococcus vestibularis sp. nov. from the human oral cavity. Int $J$ Syst Bacteriol 38, 335-339.

Whiley, R. A., Russell, R. R. B., Hardie, J. M. \& Beighton, D. (1988). Streptococcus downeii sp. nov. for strains previously described as Streptococcus mutans serotype h. Int J Syst Bacteriol 38, 25-29.

Whiley, R. A., Fraser, H. Y., Douglas, C. W. I., Hardie, J. M., Williams, A. M. \& Collins, M. D. (1990). Streptococcus parasanguis sp. nov. an atypical viridans Streptococcus from human clinical specimens. FEMS Microbiol Lett 68, 115-122.

Williams, A. M. \& Collins, M. D. (1990). Molecular taxonomic studies on Streptococcus uberis type I and II. Description of Streptococcus parauberis sp. nov. J Appl Bacteriol 68, 485-490. 